\title{
Augmented reality to facilitate students' biology mastering concepts and digital literacy
}

\author{
Zakia Nurhasanah a,1,*, Ari Widodo b,2, Riandi b,3 \\ a Departement of Biology Education, Faculty of Mathematics and Natural Science Education, Universitas Pendidikan Indonesia, \\ Jl. Dr. Setiabudhi No. 229, Kota Bandung, West Java 40154, Indonesia \\ Departement of Biology Education, Faculty of Mathematics and Natural Science Education, Universitas Pendidikan Indonesia, \\ J. Dr. Setiabudhi No. 229, Kota Bandung, West Java 40154, Indonesia \\ 'zakia2597@gmail.com *; 2 widodo@upi.edu; 3 rian@upi.edu \\ ${ }^{*}$ Corresponding author
}

\begin{tabular}{|c|c|}
\hline ARTICLE INFO & ABSTRACT \\
\hline $\begin{array}{l}\text { Article history } \\
\text { Received June 29, } 2019 \\
\text { Revised November 01, } 2019 \\
\text { Accepted November 19, } 2019 \\
\text { Published November 30, } 2019\end{array}$ & $\begin{array}{l}\text { As one of abstract concepts, nervous system requires proper media which can } \\
\text { represent the real condition. The purpose of this study was to observe the effect of } \\
\text { augmented reality (AR) on students' mastering concept and digital literacy in biology. } \\
\text { This quasi-experimental research was designed using non-equivalent control group } \\
\text { design in which the instruments were test and questionnaire. The data were analyzed } \\
\text { using independent samples t-test. The results indicated that AR gave significant positive } \\
\text { effect on students' mastering concept. However, as it has no the same effect to } \\
\text { students' digital literacy, the further observation to be done to ensure the undergirding } \\
\text { reason behind the phenomena. }\end{array}$ \\
\hline \multicolumn{2}{|c|}{$\begin{array}{l}\text { How to cite: Nurhasanah, Z., Widodo, A. \& Riandi, R. (2019). Augmented reality to facilitate students' biology mastering concepts } \\
\text { and digital literacy. JPBI (Jurnal Pendidikan Biologi Indonesia), 5(3), 481-488. doi: https://doi.org/10.22219/jpbi.v5i3. } \\
9694\end{array}$} \\
\hline
\end{tabular}

\section{INTRODUCTION}

Biology is one of the branches of science that must be studied at the elementary or secondary school level in Indonesia because the principles, concepts, and laws of biology play an essential role in solving real and environmental problems (Oranc \& Kuntay, 2019; Rau, Zheng, Guo, \& Li, 2018). Biology is included in the natural sciences course because biology is very carefully related to living things and nature. Science lessons should be a vehicle for students to find out and learn the natural surroundings directly. Science lessons also support students' skills in facing the 21st century (Kyriakou \& Hermon, 2019; Rauschnabel, Felix, \& Hinsch, 2019). Science lessons are still delivered as well as other teachings that do not emphasize on how to find out about nature systematically but with the transformation of knowledge directly from teacher to student. This makes students partially understand what has been explained. From the results of observations and interviews with teachers and students of science, lessons are still things that are feared by students because it includes difficult lessons. Students better understand natural sciences if done with practical activities compared to other businesses. 
Learning biology presents a lot of material that is difficult to see the process directly, one example of this material is the coordination system. The coordination system is one of the stuff taught in Biology in the XI grade of high school. The coordination system includes the nervous system. Especially in the matter of the nervous system. At school, they still often use blackboard media and lecture methods. This makes it quite difficult for students to understand biological material that is difficult to imagine, such as the mechanism of action of nerve cells. The way the nervous system works is truly unique and complex, so students find it difficult to imagine how stimuli can occur.

The $21^{\text {st }}$ century is marked by the rapid development of technology, where technology has an impact on education. Lots of multimedia and computer aids that provide a more interactive and innovative learning system (Limbu, Jarodzka, Klemke, \& Specht, 2018; Mikhail, Mithani, \& Ibrahim, 2019). One of the technologies that are currently famous in the education sector is augmented reality (AR). Augmented reality has recently attracted a lot of public attention as an interactive technology that allows us to interact directly with virtual objects in the real world. Augmented reality-based learning applications have been widely used as a bridge for interactive digital learning and concepts in several curricula (Bosc, Fitoussi, Hersant, Dao, \& Meningaud, 2019; Siew, Ong, \& Nee, 2019). The use of augmented reality primarily serves as a supporting tool. It helps visualize things that cannot be seen directly in its form so that it can improve learning that is directly difficult to imagine, such as in the material coordination system.

The development of increasingly advanced technology, of course, affect various sectors of human life (Ceruti, Marzocca, Liverani, \& Bil, 2019; Kwiatek, Sharif, Li, Haas, \& Walbridge, 2019). This development also plays a role in the event of learning media. Learning media are becoming increasingly exciting and more concise, although they do not reduce the essence of the material (Lee \& Wong, 2019; Lopez, Navarro, \& Crispin, 2019). One of the developments of learning media, which is currently still new, is learning media by using augmented reality.

Technology that has advanced at this time and the many availabilities of information sources will undoubtedly make it difficult for humans to find and identify which information is valid, reliable, and accurate. Not a few people are wrong in taking information sources as reference material; the result is not only misleading but also nullifies the work produced by humans because it is illegal in tracing and utilizing information sources (Dube \& Ince, 2019; Gao, Lin, Chai, \& Xie, 2019; Serravalle, Ferraris, Vrontis, Thrassou, \& Christofi, 2019). So that digital literacy skills are also essential to have, this is because part of life has depended on digital technology. Digital literacy is the ability to understand and use information from various digital sources. By having digital literacy, the ability to use digital technology will also not only develop, but will have the ability to create their technology. The low digital literacy skills in Indonesia is one of the reasons for learning technology in education, especially in learning.

Augmented reality application that is used will have an impact on the digital literacy of students because students are invited to play an active role in using the application (Crofton, Botinestean, Fenelon, \& Gallagher, 2019; Garzon \& Acevedo, 2019; Qiu, Zhou, Liu, Gao, \& Tan, 2019). Also, with the application of Augmented reality can be one of the efforts to facilitate the learning of coordination systems, especially for the nervous system material. Augmented Reality-based learning media is one of the means created to be a teacher aid in delivering content (Cao \& Cerfolio, 2019; Li, Wang, Jiao, Wang, \& Li, 2019; McLean \& Wilson, 2019). Media using video that is only displayed through a projector is considered normal so that the augmented reality application can create a different learning atmosphere and can be used on smartphones that most students already have. Learning to use augmented reality learning media will undoubtedly attract more students' interest in school.

The purpose of this study was to observe the effect of augmented reality on students mastering the concept and digital literacy in biology. The role and urgency of this research is to find out how augmented reality can facilitate digital literacy capabilities. Digital literacy capability is an essential competency for humans in the development of the 21 st-century. The results of this study will show how the role of augmented reality in facilitating digital literacy capabilities. Augmented reality in this study, if it is proven to promote digital literacy capabilities, then augmented reality is highly recommended to be implemented in learning.

\section{METHOD}

The research design in this study is nonequivalent control group design, which is one type of design from the quasi-experimental method. The design of this study consisted of two groups. The first class was the 
experimental class where the group was given treatment, namely the learning of the nervous system using instructional media, the augmented reality application, and the second group, the control class where education used PowerPoint and whiteboard learning media.

Participants involved in this study were 68 students from one of the high schools in the city of Bandung. Students consisted of 34 people in the experimental class (learning using augmented reality media) and 34 people in the control class (learning using PowerPoint media). Instruments for mastering this concept include cognitive domains on cognitive aspects of $\mathrm{C} 1-\mathrm{C} 4$. This concept mastery test is used at the pretest and posttest. The concept mastery test is given in the form of a compound choice written test regarding the material of the nervous system. Before being used, the test instruments were tested, and their feasibility analyzed through reliability testing, validity tests, distinguishing features, level of difficulty, and quality of deception using the ANATES4 application.

Student pre-test results are obtained in the form of grades ranging from 0 to 100 . Then the average of the pre-test scores in each class, both the control class and the experimental class, are calculated. In addition, the pre-test scores in the control class and the experimental class were compared and tested by means of the average difference test to determine the difference. The comparison of pre-test scores aims to determine the initial conditions of the two classes that will be used in the study. Processing the post-test value is the same as processing or analyzing the pre-test results. Post-test scores in the control class and the experimental class were calculated, then tested using the average difference test. From the post-test scores, it is known that the mastery of student concepts after learning is given. From this post-test value, it can be known the difference in the mastery of concepts between the control class and the experimental class. The data collected will mostly be analyzed quantitatively, to compare the results of the mastery of the concept of both pre-test and post-test experimental and control lessons using the t-test.

\section{RESULTS AND DISCUSSION}

The results of the study of the concept mastery of the experimental class and control class students who have been analyzed statistically by means of the average difference test. Data from the pre-test results showed that the experimental class and the control class did not differ significantly. It revealed that when before learning was carried out both students in the experimental class and the control class were in the same initial conditions so that the post-test scores were then worthy of comparison. Then the post-test results data show the results that the experimental class and the control class post-test were significantly different. The augmented reality media in accordance with the classroom conditions experienced and can prove that using augmented reality media is more effective in increasing mastery of concepts both in the mechanism of nerve cell work and other material. According to Wu, Hwang, Yang, and Chen (2018) this can be caused because augmented reality has the advantage of being able to attract students' attention to see and understand the material contained.

According to Wu et al (2013) which states that the learning approach by using augmented reality technology makes students more understanding and more comfortable to understand how it works and is not dull. Similarly, the explanation Santos et al (2016) that the role of augmented reality in learning has a positive impact, one of which is students can increase understanding of a concept because of better visualization through this technology. Learning using augmented reality applications can also help developmental patterns in students' knowledge of the coordination system material, which is quite challenging to imagine. According to Akinola (2015), the augmented reality application can clarify and improve our internal images of the world, and see how they shape our actions and decisions.

The results of mastery of concepts in the control class and the experimental class are analyzed based on the concepts learned while learning. Figure 1 shows the comparison of the results of the experimental class pre-test and the control class on each concept of the nervous system being taught. Based on Figure 1, it is shown that each concept looks slightly different, especially in the concept of the function of the nerve cell structure parts. In the concept of disturbances and abnormalities in nerve cells, the experimental class has a higher value than the control class. Namely, the control class gets a value of 63 , and the experimental class receives an amount of 71 . In each concept not too much difference. This can be caused because in accordance with the data that has been analyzed, that each class on the pre-test value has no difference. 


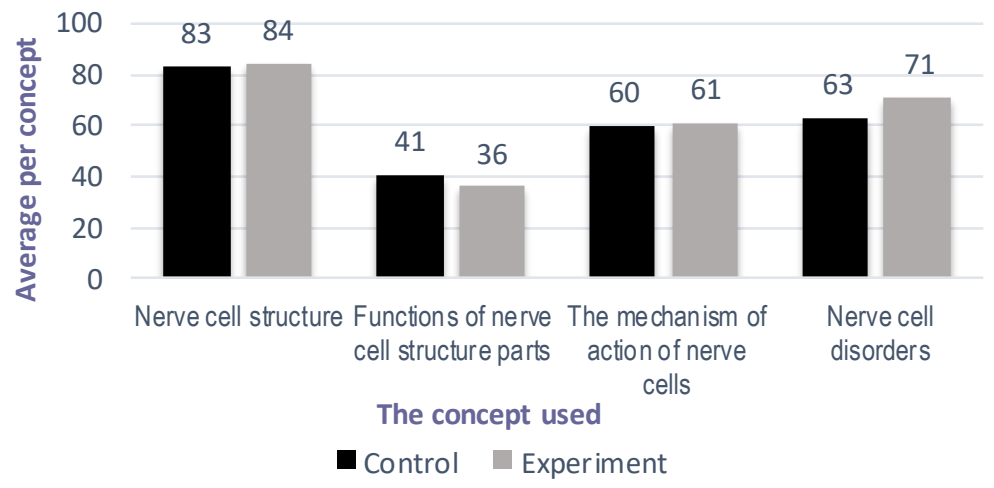

Figure 1. Pretest diagrams by Topic

Figure 2 shows the comparison of the results of the experimental class post-test and the control class on each concept of the nervous system being taught. Based on Figure 2, it is shown that the value of each concept looks different. In the concept of nerve cell structure has the highest value than other concepts, the control class gets a value of 96 , and the experimental class receives an amount of 93 . In this concept, the control class has a higher value than the experimental class, even though the comparison value is not so far away. Every concept in the post-test, control class, and experimental class already has a vast difference. This can be caused because, in learning, the experimental class uses different learning media, namely augmented reality, and the control class uses PowerPoint and whiteboard learning media.

Based on that data, the experimental class has an average value that is higher than the control class. This is also in line with Chen, Chou, and Huang (2016) that the many benefits of augmented reality informal education, the integration of the learning environment with effective learning tools, can have promising results. However, in the concept of neural cell structure, the control class has a higher value than the experimental class. According to Hsu, Lin, and Yang (2016) this can be caused by the shortcomings of the augmented reality application, namely the incomplete discussion of the material contained in the application.

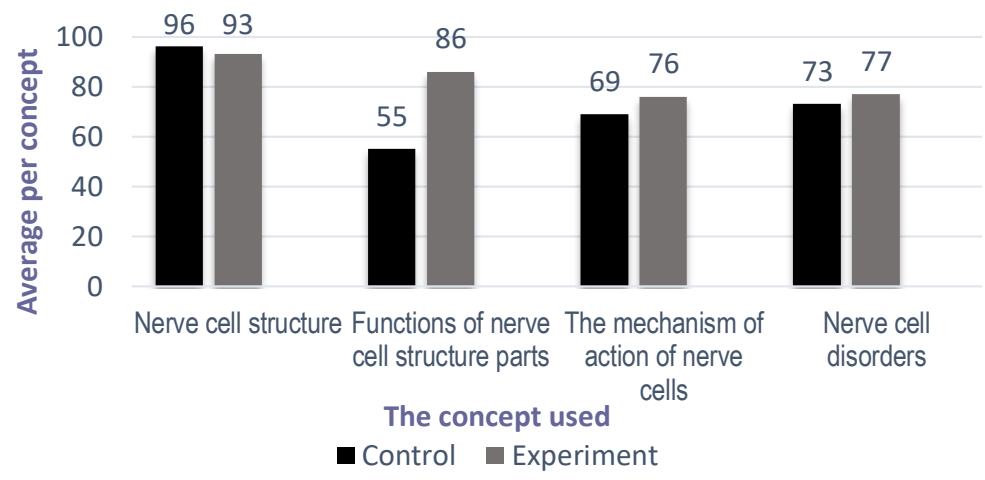

Figure 2. Posttest diagram by topic

Analysis of mastery of concepts is then performed based on cognitive levels that are facilitated in this study. The results of mastery of concepts in the control class and the experimental class are analyzed based on the concepts learned while learning. Figure 3 shows the comparison of the experimental class pre-test results and the control class at each cognitive level. Based on Figure 3 shows that for each value at each level, it looks almost the same. $\mathrm{C} 1$ cognitive level has the highest value than the other levels, namely for the control class to get a value of 73 and for the experimental class get a value of 76 . At each cognitive level at the pre-test, the control class and the experimental class do not have much difference. This can be caused because in accordance with the data that has been analyzed, that each class on the pre-test value has no difference. 


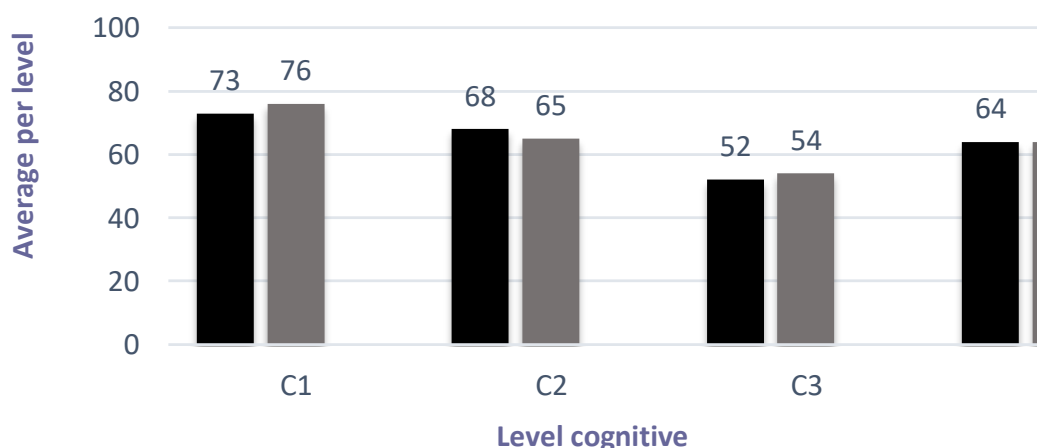

Figure 3. Pretest diagram based on cognitive levels

Based on Figure 4, each cognitive level in the posttest, the control class, and the experimental class already has quite a difference with the control class. This can be caused because, in learning, the experimental class uses different learning media, namely augmented reality, and the control class uses PowerPoint and whiteboard learning media. So the experimental class has an average value that is higher than the control class. According to Harley, Poitras, Jarrell, Duffy, and Lajoie (2016) augmented reality can make students better understand the material, because the material presented in augmented reality is described in accordance with actual conditions.

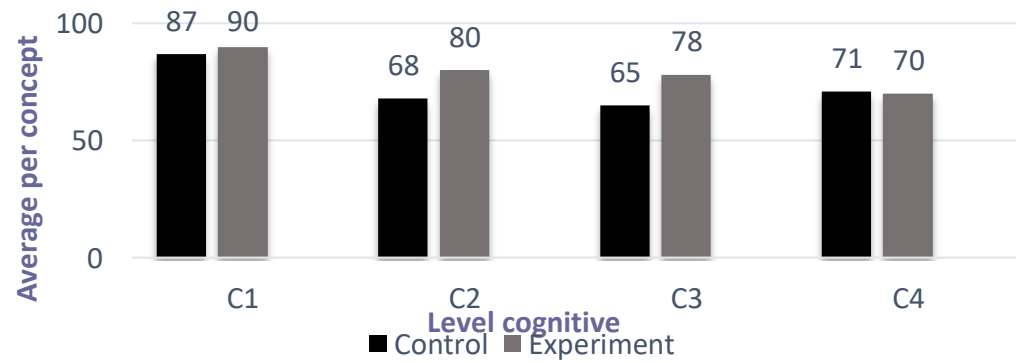

Figure 4. Posttest diagram based on cognitive levels

The perception questionnaire on digital literacy is processed and analyzed using statistical calculations through the average difference test so that the analysis data presented can be more reliable. The results obtained indicate higher than the significance level of $0.05(a=5 \%)$, which means that the questionnaire values of the experimental class and the control class are normally distributed. This average difference test uses the parametric statistical method. Following the data analysis, it was found that the experimental class and the control class questionnaire were not significantly different. It states that students' perceptions of digital literacy, both classes using augmented reality media and classes using PowerPoint media, are not much different. The average questionnaire value indicated by the experimental class and the control class also looked slightly different. Thus, both classes that use augmented reality and PowerPoint media have almost the same perception of digital literacy.

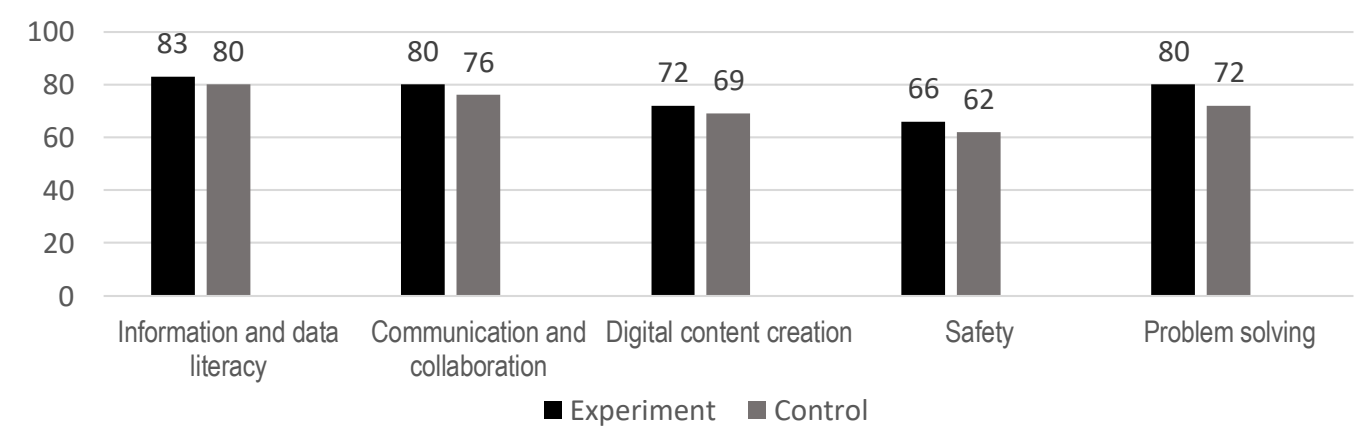

Figure 5. Comparison diagram of the average digital literacy value of the control class and experimental class 
Based on Figure 5, the highest aspect is achieved by the experimental class and the control class that is in the aspects of Information and data literacy with an average value of the experimental class is greater than the control class. Overall the percentage of the average value of students' perceptions of digital literacy in the experimental class was 76, and the control class was 72 . The control class and the experimental class had quite different perceptions of digital literacy. This can also be caused by students in the experimental class in their learning using media that utilizes augmented reality technology so that it also impacts on students' perceptions of digital literacy. According to Hidayat and Dwiningrum (2016) augmented reality can play a role in digital literacy capabilities because augmented reality makes students more often interact with technology.

Comparison of the average percentage of students' digital literacy perception values by type in the experimental class and the control class (Figure 6).

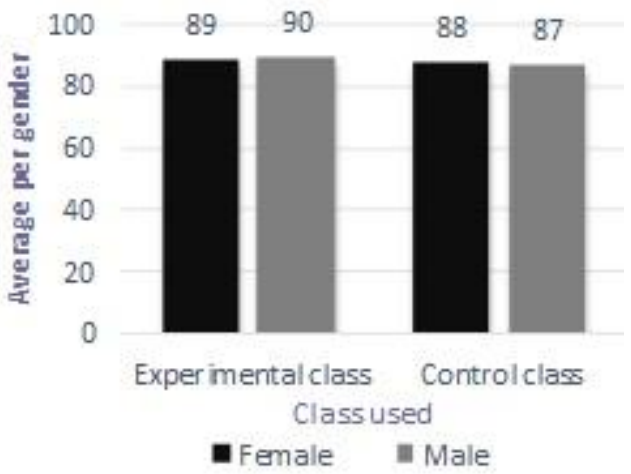

Figure 6. Analysis of student perceptions of digital literacy based on gender

Based on Figure 6, in the experimental class male students have an average percentage of students' perception values of digital literacy that is not much different and higher than women, namely for men getting 90 and for women getting 89. This is in harmony with an article submitted by Ferrer-Torregrosa et al (2016) that younger children, female sexes, and of lower social status have lower digital skills because they do less online activities than men. According to Harley et al (2016) in addition, this can occur due to environmental differences and also treatment in learning activities. Research result Rauschnabel et al (2019) explained that there are differences between male and female students in computer use. Male students have more skills than female students in using computers, especially at MS. Office, Corel Draw, Windows Media Player, and Games. However, female students have a higher frequency of using computers for chatting and email messages. Further analysis revealed that more male students than female students used computers, and male students had more digital skills knowledge than female students.

\section{CONCLUSION}

Learning by using the Augmented Reality Application has an influence on the mastery of students' nervous system concepts. In addition, students' perceptions of digital literacy in the classroom with learning using the Augmented Reality application get a greater value than in classes with learning to use PowerPoint even though the results show no significant difference.

\section{ACKNOWLEDGMENT}

Acknowledgments are addressed to those who have assisted in this research, especially high schools in the city of Bandung as a place for testing learning media and material on the neuron system.

\section{REFERENCES}

Akinola, S. O. (2015). Computer programming skill and gender difference: an empirical study. American Journal of Scientific and Industrial Research, 7(1), 1-9. doi: https://doi.org/10.5251/ajsir.2016.7.1.1.9

Bosc, R., Fitoussi, A., Hersant, B., Dao, T. H., \& Meningaud, J. P. (2019). Intraoperative augmented reality with heads-up displays in maxillofacial surgery: a systematic review of the literature and a classification 
of relevant technologies. International Journal of Oral and Maxillofacial Surgery, 48(1), 132-139. doi: https://doi.org/10.1016/j.ijom.2018.09.010

Cao, C., \& Cerfolio, R. J. (2019). Virtual or augmented reality to enhance surgical education and surgical planning. Thoracic Surgery Clinics, 29(3), 329-337. doi: https://doi.org/10.1016/j.thorsurg.2019.03.010

Ceruti, A., Marzocca, P., Liverani, A., \& Bil, C. (2019). Maintenance in aeronautics in an industry 4.0 context: the role of augmented reality and additive manufacturing. Journal of Computational Design and Engineering, 6(4), 516-526. doi: https://doi.org/10.1016/j.jcde.2019.02.001

Chen, C. H., Chou, Y. Y., \& Huang, C. Y. (2016). An augmented-reality-based concept map to support mobile learning for science. The Asia-Pacific Education Researcher, 25(4), 567-578. doi: https://doi.org/10.10 07/s40299-016-0284-3

Crofton, E. C., Botinestean, C., Fenelon, M., \& Gallagher, E. (2019). Potential applications for virtual and augmented reality technologies in sensory science. Innovative Food Science \& Emerging Technologies, 56. doi: https://doi.org/10.1016/j.ifset.2019.102178

Dube, T. J., \& Ince, G. (2019). A novel interface for generating choreography based on augmented reality. International Journal of Human-Computer Studies, 132, 12-24. doi: https://doi.org/10.1016/j.jhcs.2019. 07.005

Ferrer-Torregrosa, J., Jiménez-Rodríguez, M. A., Torralba-Estelles, J., Garzón-Farinós, F., Pérez-Bermejo, M., \& Fernández-Ehrling, N. (2016). Distance learning ects and flipped classroom in the anatomy learning : comparative study of the use of augmented reality, video and notes. BMC Medical Education, 16(230). doi: https://doi.org/10.1186/s12909-016-0757-3

Gao, Y., Lin, L., Chai, G., \& Xie, L. (2019). A feasibility study of a new method to enhance the augmented reality navigation effect in mandibular angle split osteotomy. Journal of Cranio-Maxillofacial Surgery, 47(8), 1242-1248. doi: https://doi.org/10.1016/j.jcms.2019.04.005

Garzon, J., \& Acevedo, J. (2019). Meta-analysis of the impact of augmented reality on students' learning gains. Educational Research Review, 27, 244-260. doi: https://doi.org/10.1016/j.edurev.2019.04.001

Harley, J. M., Poitras, E. G., Jarrell, A., Duffy, M. C., \& Lajoie, S. P. (2016). Comparing virtual and locationbased augmented reality mobile learning: emotions and learning outcomes. Educational Technology Research and Development, 64(3), 359-388. doi: https://doi.org/10.1007/s11423-015-9420-7

Hidayat, A., \& Dwiningrum, S. I. A. (2016). Pengaruh karakteristik gender dan motivasi belajar terhadap prestasi belajar matematika siswa SD. Jurnal Prima Edukasia, 4(1), 1-9. doi: https://doi.org/10.21831/ jpe.v4i1.7692

Hsu, Y., Lin, Y., \& Yang, B. (2016). Impact of augmented reality lessons on students' STEM interest. Research and Practice in Technology Enhanced Learning, 12(2), 6-8. doi: https://doi.org/10.1186/s4 1039-016-0039-z

Kwiatek, C., Sharif, M., Li, S., Haas, C., \& Walbridge, S. (2019). Impact of augmented reality and spatial cognition on assembly in construction. Automation in Construction, 108. doi: https://doi.org/10.1016/j.aut con.2019.102935

Kyriakou, P., \& Hermon, S. (2019). Can I touch this? using natural interaction in a museum augmented reality system. Digital Applications in Archaeology and Cultural Heritage, 12. doi: https://doi.org/10.1016/j.daa ch.2018.e00088

Lee, C., \& Wong, G. K. C. (2019). Virtual reality and augmented reality in the management of intracranial tumors: a review. Journal of Clinical Neuroscience, 62, 14-20. doi: https://doi.org/10.1016/j.jocn.2018 12.036

Li, W., Wang, J., Jiao, S., Wang, M., \& Li, S. (2019). Research on the visual elements of augmented reality assembly processes. Virtual Reality \& Intelligent Hardware, 1(6), 622-634. doi: https://doi.org/10.1016/j. vrih.2019.09.006

Limbu, B. H., Jarodzka, H., Klemke, Ro., \& Specht, M. (2018). Using sensors and augmented reality to train apprentices using recorded expert performance: a systematic literature review. Educational Research Review, 25, 1-22. doi: https://doi.org/10.1016/j.edurev.2018.07.001

Lopez, W. O. C., Navarro, P. A., \& Crispin, S. (2019). Intraoperative clinical application of augmented reality in neurosurgery: a systematic review. Clinical Neurology and Neurosurgery, 177, 6-11. doi: https://doi.org /10.1016/j.clineuro.2018.11.018

McLean, G., \& Wilson, A. (2019). Shopping in the digital world: examining customer engagement through augmented reality mobile applications. Computers in Human Behavior, 101, 210-224. doi: https://doi. org/10.1016/j.chb.2019.07.002 
Mikhail, M., Mithani, K., \& Ibrahim, G. M. (2019). Presurgical and intraoperative augmented reality in neurooncologic surgery: clinical experiences and limitations. World Neurosurgery, 128, 268-276. doi: https:/l doi.org/10.1016/j.wneu.2019.04.256

Oranc, C., \& Kuntay, A. C. (2019). Learning from the real and the virtual worlds: educational use of augmented reality in early childhood. International Journal of Child - Computer Interaction, 21, 104-111. doi: https://doi.org/10.1016/j.ijcci.2019.06.002

Qiu, C., Zhou, S., Liu, Z., Gao, Q., \& Tan, J. (2019). Digital assembly technology based on augmented reality and digital twins: a review. Virtual Reality \& Intelligent Hardware, 1(6), 597-610. doi: https://doi.org/ 10.1016/j.vrih.2019.10.002

Rau, P. L. P., Zheng, J., Guo, Z., \& Li, J. (2018). Speed reading on virtual reality and augmented reality. Computers \& Education, 125, 240-245. doi: https://doi.org/10.1016/j.compedu.2018.06.016

Rauschnabel, P. A., Felix, R., \& Hinsch, C. (2019). Augmented reality marketing: how mobile ar-apps can improve brands through inspiration. Journal of Retailing and Consumer Services, 49, 43-53. doi: https:/l doi.org/10.1016/j.jretconser.2019.03.004

Santos, M. E. C., Lübke, A. in W., Taketomi, T., Yamamoto, G., Rodrigo, M. M. T., Sandor, C., \& Kato, H. (2016). Augmented reality as multimedia: the case for situated vocabulary learning. Research and Practice in Technology Enhanced Learning, 11(4). doi: https://doi.org/10.1186/s41039-016-0028-2

Serravalle, F., Ferraris, A., Vrontis, D., Thrassou, A., \& Christofi, M. (2019). Augmented reality in the tourism industry: a multi-stakeholder analysis of museums. Tourism Management Perspectives, 32. doi: https:// doi.org/10.1016/j.tmp.2019.07.002

Siew, C. Y., Ong, S. K., \& Nee, A. Y. C. (2019). A practical augmented reality-assisted maintenance system framework for adaptive user support. Robotics and Computer-Integrated Manufacturing, 59, 115-129. doi: https://doi.org/10.1016/j.rcim.2019.03.010

Wu., Lee, S. W. Y., Chang, H. Y., \& Liang, J. C. (2013). Current status, opportunities and challenges of augmented reality in education. Computers \& Education, 62, 41-49. doi: https://doi.org/10.1016/j.com pedu.2012.10.024

Wu, P. H., Hwang, G. J., Yang, M. L., \& Chen, C. H. (2018). Impacts of integrating the repertory grid into an augmented reality-based learning design on students' learning achievements, cognitive load and degree of satisfaction. Journal Interactive Learning Environments, 26(2), 221-234. doi: https://doi.org/10.1080/1 0494820.2017.1294608 